\title{
ASPECTOS HISTÓRICOS DO TEATRO NA LEGISLAÇÃO EDUCACIONAL: uma reflexão teórico-crítica
}

\author{
Leonardo Augusto Madureira de Castro* \\ Isabella Fernanda Ferreira*
}

\begin{abstract}
Resumo: Com o intuito de melhor compreender os caminhos pelos quais o Teatro se desenvolveu dentro do âmbito educacional, este artigo busca nos principais documentos legais, tais como as Leis de Diretrizes e Bases da Educação Nacional (LDBN) que discorrem sobre arte e educação como a Lei n 9.394/96 e os Parâmetros Curriculares Nacionais (PCN's), traçar um paralelo entre as discussões de autores da área, como Barbosa e Santana e as principais mudanças e caminhos no qual o Teatro, e em consequência a Arte, sofreu ao longo de tantos anos, buscando deslumbrar possíveis encaminhamentos sobre possibilidades de enfrentamentos e novas perspectivas para a área sem sínteses téoricas em coerência com a dialética negativa proposta pela Teoria Crítica.
\end{abstract}

Palavras-chave: Teatro; Legislação; Teoria Crítica.

\section{HISTORICAL ASPECTS OF THEATER IN EDUCATIONAL LEGISLATION: a theory-critical reflection}

\begin{abstract}
In order to better understand the ways in which the theater has developed within the educational field, this article searches in the main legal documents, such as the Laws of Directives and Bases of National Education (LDBN) that discuss art and education as the Law 9,394/96 and the National Curricular Parameters (NCPs), as well as to draw a parallel between the discussions of area authors such as Barbosa and Santana and discuss the main changes and paths in which the Theater, and consequently Art, suffered during many years years, trying to dazzle possible referrals about possibilities of confrontations and new perspectives for the area without concern for theoretical syntheses in coherence with the negative dialectic proposed by the Critical Theory.
\end{abstract}

Keywords: Theater; Legislation; Critical Theory.

Submissão 09-07-18 Aceite 19-08-18

VISÃO CRÍTICA-HISTÓRICA-LEGAL

Com a intervenção dos jesuítas na educação dos colonos e nativos, por quase 200 anos, a Arte, além de muitos outros objetivos, também foi desenvolvida com a ideia de ser uma forma de catequizar os dogmas católicos vigentes na época.

As primeiras manifestações cênicas no Brasil cujos textos se preservaram são obras dos jesuítas, que fizeram teatro como instrumento de catequese. Os colonizadores portugueses haviam trazido da metrópole o hábito das representações, mas, não se ajustando elas aos preceitos religiosos, Nóbrega ${ }^{1}$ incumbiu Anchieta (1534-1597) de encenar um auto. $\mathrm{O}$ jovem evangelizador, cognominado, pela tarefa

\footnotetext{
* Ator e arte educador, graduado em Artes Cênicas e Dança pela Universidade Estadual de Mato Grosso do Sul (UEMS) e Mestre em Educação Social pela Universidade Federal de Mato Grosso do Sul(UFMS/CPAN).

* Doutora em Educação pela UNESP de Araraquara, Docente Permanente do Programa de Pós-graduação em Educação - UFMS/CPAN. Docente Colaboradora no Programa de Pós-Graduação em Educação da UFMS/Campo Grande. Uma das Fundadoras da Rede Nacional de Pesquisa - "NEXOS Teoria Crítica e Pesquisa Interdisciplinar" dividida pelas cinco regiões do Brasil com parceiros internacionais. Líder do "NEXOS - Teoria Crítica e Pesquisa Interdisciplinar - Centro-Oeste/Norte".

${ }^{1}$ Padre jesuíta português, chefe da primeira missão jesuítica de catequização nas Terras de Santa Cruz (Brasil), no século XVI.
} 
admirável de cristianização dos silvícolas, o "Apóstolo do Brasil”, tinha pendores literários diversos, e se distinguiu no gênero epistolar, na gramática e na poesia, de lirismo devoto e inspirada fatura. [...] Não será o caso de acreditar, a propósito do jesuíta, que tenha sentido a vocação irresistível do palco. Os vários autos, desiguais na forma e no resultado cênico, parecem uma aplicada composição didática de quem tinha um dever superior a cumprir: levar a fé e os mandamentos religiosos à audiência, num veículo ameno e agradável, diferente da prédica seca dos sermões. Acresce que os índios eram sensíveis à música e à dança, e a mistura das várias artes atuava sobre o espectador com vigoroso impacto. A missão catequética dos autos se cumpria assim facilmente. (MAGALDI, 2004, p. 16)

Até meados de 1800, com a expulsão dos jesuítas do Brasil em 1759, objetivo este que se estendeu além, por mais de cem anos doutrinando o modo de pensar dos educadores que se comprometiam com o ensino da Arte.

Na primeira metade do século XX, as disciplinas Desenho, Trabalhos Manuais, Música e Canto Orfeônico faziam parte dos programas das escolas primárias e secundárias, concentrando o conhecimento na transmissão de padrões e modelos das classes sociais dominantes. $\mathrm{Na}$ escola tradicional, valorizavam-se principalmente as habilidades manuais, os "dons artísticos", os hábitos de organização e precisão, mostrando ao mesmo tempo uma visão utilitarista e imediatista da arte. [...] As atividades de teatro [...] não estavam incluídas no currículo escolar como práticas obrigatórias, e somente eram reconhecidas quando faziam parte das festividades escolares na celebração de datas como Natal, Páscoa ou Independência, ou nas festas de final de período escolar. O teatro era tratado com uma única finalidade: a da apresentação. Os alunos decoravam os textos e os movimentos cênicos eram marcados com rigor. Apesar da rigidez gestual e vocal dessa atividade, a relação com a platéia era de alguma forma contemplada, tanto que se privilegiava a aprendizagem da dicção. (BRASIL, 1998, p. 23-4)

Segundo o PCN-Arte de 98 percebemos uma crítica em relação ao desenvolvimento do Teatro no ambiente escolar, que se perpetua até os dias de hoje. Tal visão "utilitarista e imediatista da arte" e o fato das produções teatrais somente ser reconhecidas "quando faziam parte das festividades escolares na celebração de datas como Natal, Páscoa ou Independência, ou nas festas de final de período escolar", desenvolve a clara percepção de esta ser uma demonstração artística rebaixada a categoria de ferramenta docente ou de entretenimento dentro dos muros da escola. Mesmo o PCN, ao apresentar o teatro como tendo "uma única finalidade: a da apresentação", nos lança a questionar sobre a real "finalidade" do teatro dentro da escola.

Sobre Arte, os teóricos críticos Adorno e Horkheimer (1985) já estabeleciam parâmetros de discussão sobre o que poderia ser agradável no ensino da Arte dentro deste olhar eventista sobre o teatro. Ao estabelecimento de finalidades 
como apresentações, a legislação e a prática educativa do teatro se desenvolvem com ideias simplórias de diversão e entretenimento, apenas. Para esta categoria entendemos o conceito de indústria cultural proposto pelos autores que explica a semiformação cultural do pensamento ao longo dos anos, também proporcionada pela ideia de diversão a qual o teatro era ligado.

Todavia, a indústria cultural permanece a indústria da diversão. Seu controle sobre os consumidores é mediado pela diversão, e não é por um mero decreto que esta acaba por se destruir, mas pela hostilidade inerente ao princípio da diversão por tudo aquilo que seja mais do que ela própria. Como a absorção de todas as tendências da indústria cultural na carne e no sangue do público se realiza através do processo social inteiro, a sobrevivência do mercado neste ramo atua favoravelmente sobre essas tendências. [...] A verdade em tudo isso é que o poder da indústria cultural provém de sua identificação com a necessidade produzida, não da simples oposição a ela, mesmo que se tratasse de uma oposição entre a onipotência e impotência. A diversão é o prolongamento do trabalho sob o capitalismo tardio. Ela é procurada por quem quer escapar ao processo de trabalho mecanizado, para se pôr de novo em condições de enfrenta-lo. [...] Eis aí a doença incurável de toda diversão. (ADORNO \& HORKHEIMER, 1985, p. 111-112)

Esta diversão fez parte das concepções práticas do teatro desenvolvido nas salas de aula em sua forma mais básica. Desde o tempo das primeiras invasões ao Brasil, aos processos de aculturação e da troca das riquezas por bens toscos temos amostras dos processos estipulados como indústria cultural por Adorno e Horkheimer (1985). Com os processos de industrialização no Brasil, com a chegada de mais comunidades europeias e seguidamente por colonos de todas as regiões do globo, o desenvolvimento da indústria estabeleceu ainda mais um lugar periférico do teatro nos sistemas educacionais. De força transformadora, política e emancipatória, o teatro fora cada vez mais sendo subdesenvolvido até finalmente chegar a simplória categoria de produto, mercadoria cultural da indústria.

As mercadorias culturais da indústria se orientam [...], segundo o princípio de sua comercialização e não segundo seu próprio conteúdo e sua figuração adequada. Tôda a práxis da indústria cultural transfere, sem mais, a motivação do lucro às criações espirituais. A partir do momento em que essas mercadorias asseguram a vida de seus produtores no mercado, elas já estão contaminadas por essa motivação. (ADORNO, 1987, p. 288)

Vejamos que o teatro é também objeto de estudo de outros autores quando estes o percebem sendo instrumentalizado. Além de documentos governamentais, temos também a percepção crítica desta época, marcada pela colonização, por parte de pesquisadores da área como Santana (2002): 
Desde o período colonial o teatro vem sendo utilizado como instrumento educativo, embora a ação dos padres jesuítas tenha se limitado à catequese, face à impossibilidade de uma atuação mais rigorosa, em termos quantitativos e qualitativos, nas escolas de aprender a ler e contar. Com as reformas do Marquês de Pombal e a expulsão dos jesuítas, o sistema de ensino pouco foi alterado [...]. (SANTANA, 2002, p. 247-248)

E Hansted e Gohn (2013):

No Brasil, o teatro foi largamente utilizado pelos jesuítas, como instrumento de catequização dos índios. [...] Nesse sentido, vale mencionar que nas encenações promovidas pelos jesuítas em território nacional, nota-se a incorporação de músicas, danças, instrumentos musicais, adereços e aspectos do cotidiano da vida dos nativos, em uma clara estratégia de aproximação entre as duas culturas. (HANSTED; GOHN, 2013, p. 203)

Tal estratégia de aproximação é típica do colonizador que busca transformar o sujeito colonizado em escravo passivo de sua própria cultura submissa à cultura estrangeira. Esse processo só é possível a medida que a cultura daqueles que sofrem tal invasão não perdem seus costumes, não lhes são arrancados à força suas crenças, mas, pelo contrário, são substituídas pouco a pouco pela cultura do invasor. Essa cultura aculturada é resultado de um processo designado como semiformação por Adorno e Horkheimer (1985). Semiformação, pois os que são submetidos a um distanciamento de sua cultura o fazem por também acreditar que esta miscigenação cultural fortalece a base cultural de um povo, mas, como no caso dos nativos e dos europeus, foi justamente o contrário. Tais processos de dominação dos povos originais pelos europeus do século XVI os ajudaram a enxergar os povos que aqui encontraram como simples engrenagens, como coisas a serem exploradas, inclusive pela catequização teatralizada. Adorno e Horkheimer (1985), explicam a dominação e suas consequências.

O preço da dominação não é meramente a alienação dos homens com relação aos objetos dominados; com a coisificação do espírito, as próprias relações dos homens foram enfeitiçadas, inclusive as relações de cada indivíduo consigo mesmo. [...] o industrialismo coisifica as almas. O aparelho econômico, antes mesmo do planejamento total, já provê espontaneamente as mercadorias dos valores que decidem sobre o comportamento dos homens. A partir do momento em que as mercadorias, com o fim do livre intercâmbio, perderam todas suas qualidades econômicas salvo seu caráter de fetiche, este se espalhou como uma paralisia sobre a vida da sociedade em todos os seus aspectos. As inúmeras agências da produção em massa e da cultura por ela criada servem para inculcar no indivíduo os comportamentos normalizados como os únicos naturais, decentes, racionais. [...] Seu padrão é a autoconservação, a assemelhação bem ou malsucedida 
à objetividade da sua função e aos modelos colocados para ela. (ADORNO \& HORKHEIMER, 1985, p. 34)

Podemos aqui estabelecer uma relação entre os povos originais e o que os autores chamam de mercadorias, pois assim eram tratados. E a Arte facilita essa fetichização do ser humano quando transformada em um instrumento de alienação. E essa transformação é dada partindo do princípio, ou seja, do ensino, dos primeiros contatos. Percebe-se então que as Artes tinham sempre um lugar afastado dentro da educação brasileira e este lugar era dado com atividades manuais, artesãs, com fins de aprendizado geométrico ou ilustrativo, enfim, com finalidades utilitaristas e não artísticas. A Arte é um dos campos mais humanizadores do conhecimento, mas se transformada em saber com simples finalidade utilitarista, é o mesmo que ensinar a utilizar, ou seja, coisificar essa humanidade.

A arte na escola já foi considerada matéria, disciplina, atividade, mas sempre mantida à margem das áreas curriculares tidas como mais "nobres". Esse lugar menos privilegiado corresponde ao desconhecimento, em termos pedagógicos, de como se trabalhar o poder da imagem, do som, do movimento e da percepção estética como fontes de conhecimento. (BRASIL, 1998, p. 26)

Em 20 de dezembro de 1961 fora instituída a primeira LDB, a Lei 4024/61 que organizava as matérias e o currículo escolar dividindo-o principalmente entre primário, ginásio e colegial. Uma gama de matérias fora definida, entre elas, desenho, o que mais se aproximava de uma educação artística na época. No grau médio, separado entre matérias obrigatórias e optativas a Arte era considerada como uma atividade complementar, como cita a Lei 4.024/61, no Art. 38, Inciso IV do Capítulo I, Título VII, à iniciação artística:

Título VII - Da Educação de Grau Médio

Art. 38 - Na organização no ensino do grau médio, serão observadas as seguintes normas:

$[\ldots]$

IV - Atividades complementares de iniciação de atividades artísticas (BRASIL, 1961, Lei n 4.024 ).

Uma década depois com a Lei 5692/1971 a educação artística passa a ser integrada obrigatoriamente dentro do currículo escolar, porém de forma polivalente. Segundo a lei, o professor era obrigado a ensinar Música, Artes Plásticas e Teatro de forma a se obter o desenvolvimento das potencialidades do aluno integralmente, mas não pensando em sua formação sensível e sensorial, estética e criativa, mas sim em uma forma do aluno ter 
acesso a simples atividades artísticas para amplificar no aluno seu gosto pelas artes, como observado em seu artigo $7^{\circ}$ :

Art. $7^{\circ}$ - Será obrigatória a inclusão de Moral e Cívica, Educação Física, Educação Artística e Programa de Saúde nos currículos plenos dos estabelecimentos de ensino de $1^{\circ}$ e $2^{\circ}$ graus, observando-se quanto o primeiro disposto no Decreto-Lei $\mathrm{n}^{\circ}$ 869, de 12 de setembro de 1969 (BRASIL, 1971, Lei 5.962).

Esta obrigatoriedade da chamada Educação Artística nos currículos plenos foi importante para dar início a discussões sobre o papel da Arte na escola, porém do implemento de tal obrigatoriedade, grandes conflitos entre os arte-educadores e o currículo escolar pretendido foram gerados, não sendo este um bom começo para se pensar a educação artística, como veremos na contradição a seguir:

Em 1971, pela Lei de Diretrizes e Bases da Educação Nacional, a arte é incluída no currículo escolar com o título de Educação Artística, mas é considerada "atividade educativa" e não disciplina, tratando de maneira indefinida o conhecimento.

A introdução da Educação Artística no currículo escolar foi um avanço, principalmente pelo aspecto de sustentação legal para essa prática e por considerar que houve um entendimento em relação à arte na formação dos indivíduos. No entanto, o resultado dessa proposição foi contraditório e paradoxal. Muitos professores não estavam habilitados e, menos ainda, preparados para o domínio de várias linguagens, que deveriam ser incluídas no conjunto das atividades artísticas (Artes Plásticas, Educação Musical, Artes Cênicas).

[...] Com a polivalência as linguagens artísticas deixaram de atender às suas especificidades, constituindo-se em fragmentos de programas curriculares ou compondo uma outra área. (BRASIL, 1998, p. 26-7)

Segundo o documento governamental, apesar das dificuldades e de nos apresentar as contradições, houve um "avanço, principalmente pelo aspecto de sustentação legal para essa prática e por considerar que houve um entendimento em relação à arte na formação dos indivíduos.” Mas a este processo foi dado um caráter político controlador às ideias de levar a Arte a todos pela educação. Aumentava-se assim o poder dos educadores da Arte, mas este poder vinha com uma grande dificuldade subjetiva e que fora logo percebida.

O preço que os homens pagam pelo aumento de seu poder é a alienação daquilo sobre o que exercem o poder. $\mathrm{O}$ esclarecimento comporta-se com as coisas como o ditador se comporta com os homens. Este conhece-os na medida em que pode manipulá-los. O homem de ciência conhece as coisas na medida em que pode fazê-las. É assim que seu em-si torna para-ele. Nessa metamorfose, a essência das coisas revela-se como sempre a mesma, como substrato da dominação. (ADORNO \& HORKHEIMER, 1985, p. 20, grifo do autor). 
Para entender a dificuldade implícita nos acordos em relação à Arte e à Educação vejamos do que trata Barbosa em um artigo de 1989, que busca uma visão ainda mais crítica da realidade desenvolvida pela obrigatoriedade legal da polivalência, pensando também nos interesses políticos existentes por detrás do estabelecimento da Educação Artística:

\begin{abstract}
Artes têm sido uma matéria obrigatória em escolas primárias e secundárias $\left(1^{\circ}\right.$ e $2^{\circ}$ graus $)$ no Brasil já há 17 anos. Isto não foi uma conquista de arte-educadores brasileiros mas uma criação ideológica de educadores norte-americanos que, sob um acordo oficial (Acordo MEC-USAID) ${ }^{2}$, reformulou a Educação Brasileira, estabelecendo em 1971 os objetivos e o currículo configurado na Lei Federal n ${ }^{\circ} 5692$ denominada "Diretrizes e Bases da Educação" [...] Esta foi uma maneira de profissionalizar mão-de-obra barata para as companhias multinacionais que adquiriram grande poder econômico no País sob o regime da ditadura militar de 1964 a 1983 . No currículo estabelecido em 1971, as artes eram aparentemente a única matéria que poderia mostrar alguma abertura em relação às humanidades e ao trabalho criativo, porque mesmo filosofia e história haviam sido eliminadas do currículo. (BARBOSA, 1989, p.170)
\end{abstract}

Percebe-se uma questão dialética, política e territorial entre o documento federal e as impressões de Barbosa (1989). Foi justamente entre tais diálogos que a luta pela arte na educação foi sendo estabelecida no Brasil. Apenas em 1996 com a Lei no 9.394/96 a Arte é considerada obrigatória na educação básica: conforme o § $2^{\circ}$ do artigo 26, segundo a mais recente redação dada pela Lei $\mathrm{n}^{\mathrm{o}} 13.415$, de 16 de fevereiro de 2017: “§ 2ㅇ O ensino da arte, especialmente em suas expressões regionais, constituirá componente curricular obrigatório da educação básica.” (BRASIL, 2017). Com esta lei, podem-se criar infinitas possibilidades de se engendrar a aproximação do aluno com sua realidade artística, com os artistas de sua comunidade e com sua própria formação criativa. Dentro da Lei $\mathrm{n}^{\mathrm{o}} 13.278$ podemos destacar o parágrafo que trata do artigo 26 da Lei $\mathrm{n}^{\circ}$ 9.394, de 1996, sendo este importante para o Teatro: $\S 6^{\circ}$ As artes visuais, a dança, a música e o teatro são as linguagens que constituirão o componente curricular de que trata o $§ 2^{\circ}$ deste artigo. (Redação dada pela Lei $n^{\circ} 13.278$, de 2016) (BRASIL, 2016). No parágrafo $6^{\circ}$, especifica-se as quatro linguagens artísticas, o que fortifica legalmente a luta dos professores pelo ensino da arte, visto que todas as áreas são importantes.

Ainda tendo o LDB 96 como referência, podemos citar o artigo $3^{\circ}$, importante também para o desenvolvimento do Teatro dentro do ambiente escolar.

2 Nome de um acordo que desenvolveu uma série de convênios realizados a partir de 1964, durante o regime de ditadura brasileira, entre o Ministério da Educação (MEC) e a United States Agency for International Development (USAID). 
Art. $3^{\circ} \mathrm{O}$ ensino será ministrado com base nos seguintes princípios:

[...]

II - liberdade de aprender, ensinar, pesquisar e divulgar a cultura,

o pensamento, a arte e o saber;

$[\ldots]$

X - valorização da experiência extra-escolar;

[...]. (BRASIL, 1996)

No artigo $3^{\circ}$, os princípios destacados valorizam a necessidade de um aprendizado livre, levando em consideração as diferentes origens culturais que o aluno possa vir a ter e a conhecer, bem como sua aprendizagem fora da sala de aula, dando importância ao seu conhecimento adquirido além dos muros da escola.

Referindo-se às especificidades do ensino fundamental e médio, os artigos $32 \mathrm{e}$ 35 trazem importantes considerações para o olhar do desenvolvimento da compreensão social e crítica do aluno, esclarecendo o objetivo maior da educação ao trabalhar para formar cidadãos críticos, emancipados e autônomos dentro de seus anseios para com seu lugar no mundo. São eles:

Art. 32. O ensino fundamental obrigatório, com duração de 9 (nove) anos, gratuito na escola pública, iniciando-se aos 6 (seis) anos de idade, terá por objetivo a formação básica do cidadão, mediante: (Redação dada pela Lei ${ }^{\circ} 11.274$, de 2006)

[...]

II - a compreensão do ambiente natural e social, do sistema político, da tecnologia, das artes e dos valores em que se fundamenta a sociedade;

[...]

Art. 35. O ensino médio, etapa final da educação básica, com duração mínima de três anos, terá como finalidades:

$[\ldots]$

III - o aprimoramento do educando como pessoa humana, incluindo a formação ética e o desenvolvimento da autonomia intelectual e do pensamento crítico; [...] (BRASIL, 1996)

Depois destes exemplos o ensino da Arte, inclusive o Teatro, ainda caminhou por muitas discussões até os dias de hoje. Em sua dissertação de mestrado denominada “Teatro na escola: da lei à lida", Moraes (2011) explica que o teatro ainda apontou para dois movimentos distintos dentro da educação. ${ }^{3}$

A prática do jogo dramático, a partir do movimento da Escola Nova e até mesmo do desenvolvimento da Psicologia, no inicio do século XX, começa a ser introduzida na escola como um recurso didático para $\mathrm{O}$ ensino de outros conteúdos escolares, como Português, Geografia, História. Essa possibilidade de ensino é denominada, no campo acadêmico, como corrente contextualista ou instrumental, por utilizar a arte como instrumento de ensino para outras áreas. ${ }^{4}$

\footnotetext{
${ }^{3}$ Vemos aqui um exemplo teórico do que se passa com a Arte e com a Educação em seus entremeios. Para isso é necessário a descrição de todos os aspectos apresentados por Moraes, em especial dos autores por ela trazidos a este trabalho.

${ }^{4}$ (Nota do original) Como uma das principais precursoras deste movimento destaca-se Olga Reverbel.
} 
[...] Com a influência de Herbert Read, filósofo inglês que desenvolveu a idéia da educação através da arte, isto é, ver a arte não apenas como um auxílio da educação, mas, reconhecê-la pelo seu processo que possibilita o conhecimento, o teatro começa a ser pensado na educação escolar de uma forma a superar seu uso como ferramenta para alcançar conteúdos extrateatrais. Essa abordagem pedagógica da arte-educação é chamada corrente essencialista ou estética [...]. (MORAES, 2011, p. 23-24)

De posse de tal conhecimento, parece que o Teatro continua sendo base para a experiência no âmbito escolar desde o início da história da Educação no Brasil, o que justifica ainda mais a necessidade de se levantar novos questionamentos sobre a área.

Importante mencionar que se discute aqui os caminhos legais do teatro e da Arte na escola. Lancemos nosso olhar para uma das atualizações mais recentes sobre a Base Comum Curricular, a Lei 13.145, conhecido como a lei da "Reforma do Ensino Médio", mais especificamente o artigo $3^{\circ}$, que traz a seguinte redação (aqui destacados os conteúdos referentes ao ensino da Arte):

Art. $3^{\circ}$ A Lei $\mathrm{n}^{\circ}$ 9.394, de 20 de dezembro de 1996, passa a vigorar acrescida do seguinte art. 35-A:

“Art. 35-A. A Base Nacional Comum Curricular definirá direitos e objetivos de aprendizagem do ensino médio, conforme diretrizes do Conselho Nacional de Educação, nas seguintes áreas do conhecimento: I - linguagens e suas tecnologias; [...] $\S 2^{\circ}$ A Base Nacional Comum Curricular referente ao ensino médio incluirá obrigatoriamente estudos e práticas de educação física, arte, sociologia e filosofia. $\S 3^{\circ} \mathrm{O}$ ensino da língua portuguesa e da matemática será obrigatório nos três anos do ensino médio, assegurada às comunidades indígenas, também, a utilização das respectivas línguas maternas.

[...] (BRASIL, Lei $\left.\mathrm{n}^{\mathrm{o}} 13.415,2017\right)$

De posse deste artigo, lançamos um questionamento sobre o futuro da Arte na educação, uma vez que o artigo 35-A especifica no $\S 2^{\circ}$ a necessidade obrigatória de se incluir no currículo do ensino médio a arte, mas, como implícito no $\S 3^{\circ}$, não deixa claro se esta obrigatoriedade da arte se fará presente nos três anos do ensino médio abrindo assim interpretações diversas. Faz-se também necessário manter um olhar sobre tais questões, uma vez que (mais uma vez), a qualidade do ensino da Arte (e consequentemente do teatro) no futuro é incerta.

\section{UM OLHAR CRÍTICO SOBRE A FORMAÇÃO DE PROFESSORES DE ARTE}

Historicamente o teatro é levado para dentro da sala de aula com propostas rasas de ensino e emancipação tanto social, quanto política e artística. A esta parca formação dá-se a responsabilidade também pelas políticas públicas e leis ambíguas que dão margem 
para marginalizar o teatro. Aliado a isso, a visão social em relação ao teatro é ainda muito simplista, de caráter preconceituoso e desinteressado. Não existem então políticas específicas para a regulamentação do ensino direcionado ao teatro, por haver $\mathrm{o}$ entendimento que este se enquadra nas políticas formatadas para a Arte em geral. Mas percebe-se que a Arte, por si só, já é vista sem uma postura séria e contundente, sem o parecer de pessoas que realmente conhecem dos pormenores do fazer artístico e podem, por sua vivência adquirir um lugar de fala em relação à Arte em congruência com a Educação, principalmente se levarmos em consideração o fato de todos estarmos cercados pela indústria cultural e ela influenciar diretamente na formação (ou semiformação) dos sujeitos que se propõe (ou são obrigados pelo sistema educativo) à estudar Arte. Talvez por isso este pequeno estudo sobre os aspectos históricos do teatro na legislação educacional necessita buscar discussões em relação à formação dos profisssionais que disseminarão os estudos teatrais. Para isso é essencial que este profissional tenha uma boa formação.

É na formação do ser sensível, através do ensino das linguagens expressivas [...], que o professor de arte estará colaborando para formar o sujeito que se apropriará do seu discurso e construirá a sua autonomia. (VALENTE, 1993, p. 65)

Pensando nas consequências que a Federação, os Estados e Municípios sofrem com as buscas pela melhoria da educação de todos os cidadãos, principalmente no que concerne ao desenvolvimento da sensibilidade e da cultura, entendemos - inclusive pelo tamanho de nosso país - que esta não é tarefa fácil.

Com a necessidade política de dar escola a todos, o ensino foi progressivamente massificado e os professores rebaixados a um lugar secundário no processo ensino-aprendizagem. A indústria cultural, através da farta editoração e distribuição dos livros didáticos — que facilitava o ensino e padronizava a aprendizagem —, através das novelas, dos vídeos, dos softwares educativos, tomou de assalto a sala de aula e reduziu drasticamente os resquícios de autonomia ainda sonhados na educação formal. $\mathrm{O}$ método predominante na aprendizagem se constituiu como o "aprender a aprender". [...] Nesse processo educacional, inicialmente o aluno torna-se o centro e o artífice de sua aprendizagem, pela aplicação de métodos ativos, de dinâmicas de grupo, da valorização da pesquisa individual; mas, logo depois, a centralidade é assumida pelos aparelhos tecnológicos, esses novos seres inteligentes, aprendentes e fascinantes. (PUCCI, 2009, p. 74-75)

Formar-se educador, ainda mais em uma área que não possui uma legislação forte e que, com o advento do artigo 35-A dentro da Lei 9.394/96, perde ainda mais poder interpretativo, entendemos que futuramente as dificuldades irão ser ainda mais visíveis para o artista educador, ou para o educador de Arte. Ainda assim, com o passar 
dos anos, os sistemas, com ajuda das grandes tecnologias e dos ideários de globalização, se complicam ainda mais, o que trará ainda mais uma semiformação apenas informativa aos estudantes.

Quanto mais complicada e mais refinada a aparelhagem social, econômica e científica, para cujo manejo o corpo já há muito foi ajustado pelo sistema de produção, tanto mais empobrecidas as vivências de que ele é capaz. [...] A regressão das massas, de que hoje se fala, nada mais é senão a incapacidade de poder ouvir o imediato com os próprios ouvidos, de poder tocar o intocado com as próprias mãos: a nova forma de ofuscamento que vem substituir as formas míticas superadas. Pela mediação da sociedade total, que engloba todas as relações e emoções, os homens se reconvertem exatamente naquilo contra o que se voltara a lei evolutiva da sociedade, o princípio do eu: meros seres genéricos, iguais uns aos outros pelo isolamento na coletividade governada pela força. [...] São as condições concretas do trabalho na sociedade que forçam o conformismo [...]. [...] Essa necessidade lógica, porém, não é definitiva. Ela permanece presa à dominação, como seu reflexo e seu instrumento ao mesmo tempo. (ADORNO \& HORKHEIMER, 1985, p. 40-41)

É papel do profissional das Artes dentro da educação fornecer então possibilidades para a emancipação do corpo deste mundo dessensibilizado. Adorno (2005) explica justamente o que se passa com a generalização da Arte dentro das políticas públicas e das leis relacionadas quando trata do ser semiculto.

$\mathrm{O}$ semiculto se dedica à conservação de si mesmo sem si mesmo. Não pode permitir, então, aquilo em que, segundo toda teoria burguesa, se constituía a subjetividade: a experiência e o conceito. Assim procura subjetivamente a possibilidade da formação cultural, ao mesmo tempo, em que, objetivamente, se coloca todo contra ela. A experiência [...] fica substituída por um estado informativo pontual, desconectado, intercambiável e efêmero, e que se sabe que ficará borrado no próximo instante por outras informações. Em lugar do temps durée, conexão de um viver em si relativamente uníssono que se desemboca no julgamento, se coloca um "É isso" sem julgamento [...]. A semiformação é uma fraqueza em relação ao tempo, à memória, única mediação que realiza na consciência aquela síntese da experiência que caracterizou a formação cultural em outros tempos. Não é por acaso que o semiculto faz alarde de sua má memória, orgulhoso de suas múltiplas ocupações e da conseqüiente sobrecarga. (ADORNO, 2005, p. 15, grifo do autor)

Tamanha semiformação já é observada nas leis, uma vez que ela abrangem a obrigatoriedade da Arte, mas não estabelecem o nível mínimo de qualidade desta obrigatoriedade. Se pensarmos nas barbaridades cometidas no período da Segunda Grande Guerra, por exemplo, teremos um soberano ditador que amava as Artes. Mas ter conhecimento artístico não o impediu de se tornar desumano. Os grandes Césares 
da Roma antiga possuíam um alto desenvolvimento cultural e agregavam a cultura dos povos conquistados para os manterem subjugados, elevando consequentemente seu conhecimento artístico, o que não os impedia de matarem e destruírem inúmeras lideranças para concretizarem sua dominação. As inúmeras religiões sobre o globo são fontes de inspiração para a cultura e a Arte desenvolvendo ao longo dos séculos incríveis técnicas e obras para honra de suas crenças, o que não os impede de matarem, queimarem e destruírem também em nome de suas crenças. A Arte por si só tem caráter emancipatório, político, humanista e libertador, porém se atravessada por outros interesses, a transforma também em arma, tão letal quanto as utilizadas pelos ditadores.

É preciso e urgente que a escola tome ou retome em suas mãos o processo de formação cultural (die Bildung), que favoreça o esclarecimento, a reflexão crítica e as formas de resistência ao império cada vez mais dominante das máquinas sobre as pessoas, pois o progresso da ciência e da tecnologia caminha em sentido oposto ao progresso da humanidade do homem, e fortalece um modo de ser acrítico, pré-reflexivo, não racional e não espiritual. (PUCCI, 2006, p. 13-14)

Sendo assim é preciso retomar dentro da formação de todos os professores e consequentemente de seus educandos o poder revolucionário da Arte, como explica Chaves e Ribeiro (2014):

A arte pode ser revolucionária em vários sentidos. Em sentido restrito, quando apresenta uma mudança radical no estilo e na técnica (vanguarda) [...]. Mas também [...] em sua configuração estética, quando apresenta ausência de liberdade do existente e indica as forças que se rebelam contra isso; quando rompe com a realidade reificada e aponta horizontes de transformação; quando subverte as formas de percepção e compreensão e deixa transparecer um teor de verdade, de protesto e de promessa na linguagem e na imagem. (CHAVES; RIBEIRO, 2014, p.14-15)

Tal possibilidade é muito mais possibilitada pela formação do professor (tanto na acadêmica quanto na informal ou em cursos livres) do que pelas leis por si só. O próprio estudo e prática do teatro já produz tal efeito revolucionário. Ao desenvolver estudos dentro da sala de aula em cima dos conteúdos da arte, com jogos cênicos e teatrais é possível criar dimensões estéticas de aprendizagem.

Para Marcuse, a arte é política, apresenta universalidade, alteridade, transcendência, forma estética e negação e confirmação da realidade. A arte é objetivação e não trabalho alienado, ela realiza a sublimação e provoca sensibilidade, diferenciando-se da mercadoria que se apropria da cultura, fazendo-a esvaziar-se em seu sentido. (CHAVES; RIBEIRO, 2014, p. 12) 
Tamanha dialética apresentada por Chaves e Ribeiro (2014) ao citarem Marcuse é possível graças à produção de sentido desenvolvida ao se estudar os caminhos propostos pela Arte. É necessário se pensar além das possibilidades dadas pelos caminhos legais atuais. Estes caminhos estão recheados de pensamentos reificadores, produtores de cultura industrial e não se importam especificamente com $o$ desenvolvimento qualitativo da Arte na escola. Ainda é realidade a polivalência dentro das escolas para com a função do professor de Arte, ainda é realidade a desvalorização da Arte no currículo escolar, uma vez que existe pouco tempo para de fato se desenvolver uma aula com qualidade.

Em outras palavras a boa formação do profissional, educador da Arte, seja qual for (Teatro, Dança, Música, Visual) é o caminho mais importante e efetivo para o bom desenvolvimento de uma comunidade, uma sociedade, uma política diferenciada, humanizada. E este caminho vai além do conhecimento dos caminhos legais da Arte, atravessa a prática, tanto enquanto proponente quanto participante das produções artísticas apresentadas. É necessário demonstrar com um trabalho que vai além da sala de aula, assim como o teatro vai além dos palcos e alcança as ruas, os espaços alternativos, as praças, os centros comunitários, os hospitais e todos os lugares a onde existir vida em constante dialética.

\section{REFERÊNCIAS}

ADORNO, Theodor. Teoria da semicultura. 1959. Primeira versão. Ano IV, No 191 AGOSTO - Porto Velho, 2005. Volume XIII. Maio/Agosto.

ADORNO, Theodor, HORKHEIMER, Max. Dialética do esclarecimento: fragmentos filosóficos. Rio de Janeiro: Jorge Zahar Editor Ltda. 1985.

BARBOSA, Ana. Arte-Educação no Brasil: Realidade hoje e expectativas futuras. v. 3, p. 170-182, 1989. Disponível em: http://www.scielo.br/pdf/ea/v3n7/v3n7a10.pdf. Acesso em: 21 abr. 2018.

BRASIL. (1961) Lei de Diretrizes e Bases da Educação Nacional no 4.024/1961, de 20 de dezembro de 1961. Disponível em https://www.planalto.gov.br/ccivil_03/leis/L4024.htm Acesso em 13/01/2017 às 20 horas e 45 minutos.

. (1971). Lei de Diretrizes e Bases da Educação Nacional no 5.692/1971, de

11 de agosto de 1971 . Disponível em http://www.planalto.gov.br/ccivil_03/leis/L5692.htm. Acesso em 13/01/2017 às 20 horas e 57 minutos.

. (1996). Lei de Diretrizes e Bases da Educação Nacional no 9.394, de 20 de dezembro de 1996. Disponível em http://www.planalto.gov.br/ccivil_03/leis/L9394.htm. Acesso em 14/01/2017 às 22 horas e 14 minutos.

Secretaria de Educação Fundamental. Parâmetros curriculares nacionais: 
arte / Secretaria de Educação Fundamental. - Brasília: MEC / SEF, 1998.

Lei $\mathbf{n}^{\mathbf{0}}$ 13.278, de 2 de maio de 2016. Altera o $\S 6^{\circ}$ do art. 26 da Lei ${ }^{\circ} 9.394$, de 20 de dezembro de 1996. ed. Brasília - DF, 2016. Disponível em: http://pesquisa.in.gov.br/imprensa/jsp/visualiza/index.jsp?jornal=1\&pagina $=1 \&$ data $=$ 03/05/2016>. Acesso em 21/04/2018 às 14 horas e 21 minutos.

Lei $\mathbf{n}^{\mathbf{0}} \mathbf{1 3 . 4 1 5}$, de 16 de fevereiro de 2017. Altera as Leis $n^{\circ} \mathrm{s} 9.394$, de 20 de dezembro de 1996, que estabelece as diretrizes e bases da educação nacional, e 11.494, de 20 de junho 2007, que regulamenta o Fundo de Manutenção e Desenvolvimento da Educação Básica e de Valorização dos Profissionais da Educação, a Consolidação das Leis do Trabalho - CLT, aprovada pelo Decreto-Lei $\mathrm{n}^{\circ} 5.452$, de $1^{\circ}$ de maio de 1943 , e o Decreto-Lei $n^{\circ}$ 236, de 28 de fevereiro de 1967; revoga a Lei $n^{\circ} 11.161$, de 5 de agosto de 2005; e institui a Política de Fomento à Implementação de Escolas de Ensino Médio em Tempo Integral. Disponível em: http://www2.camara.leg.br/legin/fed/lei/2017/lei-1341516-fevereiro-2017-784336-publicacaooriginal-152003-pl.html. Acesso em 17/06/2018 às 15 horas e 37 minutos.

CHAVES, Juliana; RIBEIRO, Daviane. Arte em Herbert Marcuse: formação e resistência à sociedade unidimensional. Psicologia \& Sociedade, 26(1), 12-21. 2014.

HANSTED, Talitha; GOHN, Maria. Teatro e educação: uma relação historicamente construída. EccoS, São Paulo, n. 30, p. 199-220. 2013.

MAGALDI, Sábato. Panorama do teatro brasileiro. $6^{\text {a }}$ Ed. - São Paulo: Global, 2004. MORAES, Danielle. Teatro na escola: da lei à lida. Dissertação de Mestrado. UFSJ. São João Del-Rei, MG. 2011.

PUCCI, Bruno. A Escola e a Semiformação mediada pelas novas tecnologias. In: PUCCI, B. (Org.); ALMEIDA, Jorge de (Org.); LASTÓRIA, Luiz Antônio Calmon Nabuco (Org.). Experiência formativa \& emancipação. 1a ${ }^{a}$ ed. São Paulo: Nankin, 2009, p. 69-80.

. O riso e o trágico na indústria cultural: a catarse administrada. In: CARVALHO, A. B.; SILVA, W. C. L. Sociologia e educação: leituras e interpretações, São Paulo: AVERCAMP, 2006, p. 97-112.

SANTANA, Arão. Trajetória, avanços e desafios do teatro-educação no Brasil. In: Sala Preta, Revista do Depto. de Artes Cênicas/ ECA/USP, n. 2; São Paulo, 2002.

VALENTE, Tamara. O papel do professor de educação artística. Editora da UFPR; Educar. Rev. no 9. Curitiba. p. 59-68. 1993. 